\title{
Hubungan Pengetahuan, Sikap, dan Perilaku Personal Hygiene dengan Gejala Vaginitis pada Siswi SMPN 1 Kota Padang dan SMPN 23 Padang
}

\author{
Aulia Khatib $^{1}$, Syahredi S Adnani ${ }^{2}$, Roni Eka Sahputra ${ }^{3}$
}

\begin{abstract}
Abstrak
Ada $75 \%$ wanita di dunia menderita vaginitis sekali dalam seumur hidup dan $10 \%$ hingga $55 \%$ diantaranya tidak mengetahui bahwa mereka mengalami vaginitis. Pembentukan pengetahuan, sikap, dan perilaku personal hygiene yang baik dapat mencegah vaginitis. Tujuan penelitian ini adalah menentukan hubungan pengetahuan, sikap dan perilaku personal hygiene terhadap gejala vaginitis pada siswi SMPN 1 dan SMPN 23 Padang. Penelitian dilakukan terhadap siswi kelas VII, VIII, dan IX di SMPN tersebut pada bulan September 2018. Desain penelitian adalah cross sectional dengan teknik pengambilan sampel systematic random sampling. Kuisioner digunakan sebagai instrumen penelitian untuk mengukur tingkat pengetahuan, sikap, perilaku personal hygiene, dan gejala vaginitis pada responden. Penelitian menggunakan uji bivariat Chi-square untuk menganalisis data. Jumlah responden yang dikumpulkan adalah sebanyak 242 orang. Tingkat pengetahuan siswi mayoritas sedang, sedangkan sikap dan perilaku responden mayoritas baik. Hasil analisis bivariat menunjukkan hubungan antara pengetahuan dengan gejala vaginitis adalah $p=0,011$ di SMPN 23 dan $p=0,558$ di SMPN 1, hubungan sikap dengan gejala adalah $p=0,013$ di SMPN 23 dan $\mathrm{p}=0,458$ di SMPN 1, dan hubungan perilaku dengan gejala adalah $p=0,615$ di SMPN 23 dan $p=0,138$ di SMPN 1 . Hasil penelitian menunjukkan terdapat hubungan yang signifikan antara pengetahuan dan sikap dengan gejala vaginitis di SMPN 23 namun tidak didapatkan hubungan yang signifikan pengetahuan dan sikap terhadap gejala di SMPN 1. Tidak didapatkan hubungan yang signifikan antara perilaku dengan gejala vaginitis pada kedua populasi.
\end{abstract}

Kata kunci: pengetahuan, sikap, perilaku, personal hygiene, vaginitis

\section{Abstract}

About $75 \%$ of females have experienced vaginitis at least once in their lifetime with $10-55 \%$ are not aware for experiencing this disease. Risk of vaginitis can be prevented by increasing knowledge, attitude and practising personal hygiene correctly. The objective of this study was to investigate the relationship between knowledge, attitude and personal hygiene practice with vaginitis symptoms experienced by female students in Junior High School 1 and 23 Padang.Samples were collected from female students who were studying in 7th, 8th, and 9th grades. This study took place in September 2018 and used cross sectional design with systematic random sampling technique. Questionnaires were used to measure all the variables needed in this study. The collected data were analyzed by Chi-square.Total number of respondents for this research were 242 students who met inclusive criteria. Majority of students have intermediate level of knowledge, positive attitude and good personal hygiene practice in both schools. The results of bivariate analysis were showing that relationship between knowledge and symptoms in Junior High School 23 and 1 were $p=0,011$ and $p=0,558$, attitude and symptoms were $p=0,013$ and $p=0,458$, and practice and symptoms were $p=0,615$ and $p=0,138$ respectively, This study concluded there was significant relationship between knowledge and attitude with vaginitis symptoms experienced by respondents in Junior High School 23, but there was no relation shown by respondents in Junior High School 1. There was no significant relationship between personal hygiene practice with vaginitis symptoms by respondents in both schools.

Keywords: knowledge, attitude, practice, personal hygiene, vaginitis 
Affiliasi penulis: 1. Prodi Kedokteran Fakultas Kedokteran Universitas Andalas Padang (FK Unand), 2. Bagian Obstetri dan Ginekologi FK Unand/RSUP Dr. M.Djamil Padang, 3. Bagian Bedah Ortopedi FK Unand

Korespondensi: Aulia Khatib, Email: liakhatib@gmail.com Telp: $+6281372798757$

\section{PENDAHULUAN}

Menstruasi merupakan salah satu komponen seorang perempuan dalam melalui masa pubertas yang mana perempuan kebanyakannya menghadapi keterbatasan sosial dan kepercayaan diri sehingga bisa berkontribusi pada kesehatan mental maupun fisik. Pada saat menstruasi, personal hygiene perlu diperhatikan karena bersangkutan dengan kejadian infeksi genitalia. ${ }^{1}$ Sebanyak $75 \%$ wanita di dunia menderita vaginitis sekurang-kurangnya sekali dalam seumur hidup dan $10 \%$ hingga $55 \%$ diantaranya tidak mengetahui bahwa mereka mengalami vaginitis. Vaginitis yang tersering adalah vaginosis bakterialis, trikomoniasis, dan kandidiasis vulvovaginal. $^{2}$

Peningkatan suseptibilitas seseorang terhadap Reproductive Tract Infections (RTIs) dan Sexually Transmitted Infections (STIS) berhubungan dengan tingkat kepedulian dan praktek personal hygiene yang benar. WHO merekomendasikan untuk diadakan penelitian yang lebih lanjut mengenai hal ini. $^{3}$ Kesadaran yang kurang terhadap kesehatan alat reproduksi berkaitan dengan pengetahuan yang rendah mengenai personal hygiene, pengaruh sosiobudaya, faktor ekonomi keluarga, dan kurangnya fasilitas sanitasi yang disediakan oleh sekolah. ${ }^{4} \mathrm{Hal}$ ini menarik perhatian banyak peneliti, sehingga dilakukan penelitian di negara berkembang dengan keterbatasan fasilitas sanitasi seperti air, tisu, sabun, dan jamban, serta sumber informasi yang dibekalkan kepada seorang anak perempuan menjelang menarche. ${ }^{5}$

Pada tahun 2015, penelitian yang dilakukan pada 486 wanita dengan rentang umur 18-45 tahun di India menunjukkan bahwa pada wanita yang memakai kain yang dipakai ulang memiliki risiko terkena infeksi genitalia dua kali lipat berbanding wanita yang memakai sanitary pad sekali pakai saat menstruasi. ${ }^{6}$ Penelitian terdahulu menyatakan bahwa siswi yang berdomisili di daerah perkotaan cenderung memakai sanitary pad 2,32 kali lipat berbanding yang tinggal di pinggir kota. Hal ini disebabkan daerah kota memiliki akses yang lebih mudah untuk mendapatkan sanitary pad. ${ }^{7}$ Faktor yang memengaruhi personal hygiene lainnya adalah ketersediaan sumber informasi mengenai manajemen menarche dan menstruasi. Pendidikan dari ibu memiliki pengaruh yang besar terhadap praktek personal hygiene dan masalah ginekologi pada remaja perempuan yang baru menarche. ${ }^{8}$ Hasil penelitian oleh penelitian di India mendapatkan bahwa sebanyak $87,3 \%$ perempuan menggunakan kain dan 10,6\% menggunakan sanitary pad. Sebanyak 33,6\% disebabkan oleh kurangnya pengetahuan mengenai manajemen menstruasi. ${ }^{9}$ Bahan celana dalam berperan dalam tingkat risiko terjadinya infeksi genital. Hasil penelitian terdahulu mendapatkan sebanyak $38,1 \%$ responden masih membiarkan genitalia dalam suasana lembab walaupun telah dibersihkan dengan air karena area yang dibasuh belum sepenuhnya dikeringkan serta masih menggunakan kain yang dipakai ulang sebagai pengering. Selain itu, terdapat hubungan yang bermakna antara frekuensi mengganti sanitary pad dan celana dalam dengan infeksi genital. Hal ini akan menyebabkan ventilasi di sekitar genitalia semakin buruk sehingga menyebabkan suhu yang lembab dan kondisi yang sesuai untuk pertumbuhan mikroorganisme. ${ }^{10}$ Walaupun sudah banyak teori yang menjelaskan mengenai hubungan tingkat pengetahuan, sikap, dan perilaku terhadap personal hygiene dengan gejala vaginitis, namun beberapa penelitian seperti yang dilakukan di Tangerang mendapatkan tidak ada hubungan yang bermakna pada sikap dan perilaku vaginal hygiene remaja putri usia 13-17 tahun di daerah Pondok Cabe Ilir Tangerang Selatan dengan kejadian keputihan patologis. $^{11} \mathrm{Di}$ Indonesia, penelitian mengenai pengaruh personal hygiene terhadap timbulnya gangguan alat reproduksi seperti vaginitis masih sangat sedikit. Selain itu, peneliti tidak bisa mendapatkan data sekunder dari Dinas Kesehatan Kota Padang karena memang tidak ada program pemicuan mengenai kesehatan reproduksi yang ditargetkan terhadap siswi sekolah di Sumatera Barat. Data mengenai penderita vaginitis pada populasi pelajar sekolah di Padang juga sangat terbatas. 
Penelitian dilaksanakan pada dua lokasi yang berbeda berdasarkan letak jauhnya dengan pusat kota yaitu SMPN 1 dan SMPN 23 Padang. Berdasarkan hasil survey awal terhadap SMPN 1 adalah salah satu sekolah menengah pertama negeri yang beralamatkan di Jalan Jendral Sudirman, No.3 Kampung Jao, Padang Barat, Kota Padang. Sekolah ini terletak di pusat kota dan wilayah perkantoran dengan berbagai fasilitas dan kemudahan yang dapat ditemukan seperti bus Transpadang, bank, restoran, dan tempat berbelanja. Sekolah ini dapat diakses dengan mudah oleh kendaraan roda dua dan roda empat. Jumlah seluruh siswi yang terdaftar di SMPN 1 Padang tahun ajaran 2018/2019 di kelas VII adalah sebanyak 105, kelas VIII sebanyak 109 orang dan kelas XI sebanyak 115 orang. Majoritas pelajar berasal dari kalangan ekonomi menengah ke atas. Sekolah kedua yaitu SMPN 23 Padang juga merupakan sekolah menengah pertama negeri namun lokasi sekolah ini cukup jauh dari pusat kota. Sekolah ini beralamatkan di Jalan Koto Luar, Kapala Koto, Pauh, Padang. Sekolah ini dapat diakses dengan kenderaan roda dua maupun roda empat, namun jalannya tidak selebar jalan menuju SMPN 1 Padang. Di sekitarnya, terdapat perumahan warga dan banyak dipenuhi sawah. Jumlah siswi yang terdaftar di SMPN 23 Padang di kelas VII adalah sebanyak 101 siswi, kelas VIII sebanyak 94 siswi dan kelas XI sebanyak 117 siswi pada tahun ajaran 2018/2019, sehingga total siswi adalah sebanyak 312 siswi.

Berdasarkan yang demikian, peneliti tertarik untuk mengetahui hubungan tingkat pengetahuan, sikap dan perilaku personal hygiene terhadap gejala vaginitis pada siswi SMPN 1 dan SMPN 23 Padang.

\section{METODE}

Jenis penelitian ini adalah studi analitik dengan metode potong lintang (cross-sectional) yang dilakukan di SMPN 1 dan SMPN 23 Padang dalam periode bulan Mei hingga Oktober 2018.

Populasi pada penelitian ini adalah siswi kelas VII,VIII, dan IX SMPN 1 dan SMPN 23 Padang kelas VII, VIII, dan XI. Peneliti juga akan menjadikan 120 siswi dari SMPN 23 Padang sebagai sampel dengan rincian yang sama.
Data yang dikumpulkan adalah data primer yang berasal dari kuesioner penelitian terhadap siswi di kedua sekolah.

\section{HASIL}

Penelitian telah dilakukan di kedua sekolah terhadap siswi SMPN 1 dan SMPN 23 Padang pada bulan September 2018. Peneliti telah mengambil sebanyak 136 siswi di SMPN 1 dan 134 siswi di SMPN 23 Padang untuk dijadikan responden. Dari sampel tersebut, peneliti mendapatkan sebanyak 14 responden dari SMPN 1 dan 13 responden dari SMPN 23 merupakan drop out karena tidak mengisi kuesioner dengan lengkap. Namun, peneliti telah memenuhi syarat jumlah pengambilan sampel minimal yaitu 121 sampel dari masing-masing sekolah.

Tabel 1. Distribusi karakteristik responden di SMPN 1 dan SMPN 23 Padang menurut pendidikan terakhir orang tua

\begin{tabular}{|c|c|c|c|c|}
\hline \multirow{2}{*}{ Variabel } & \multicolumn{2}{|c|}{ SMPN 1} & \multicolumn{2}{|c|}{ SMPN 23} \\
\hline & $f$ & $\%$ & $f$ & $\%$ \\
\hline \multicolumn{5}{|l|}{ Pendidikan Terakhir } \\
\hline \multicolumn{5}{|l|}{ Ibu } \\
\hline SD & 0 & 0 & 11 & 9.1 \\
\hline SMP & 2 & 1.7 & 32 & 26.4 \\
\hline SMA & 31 & 25.6 & 66 & 54.5 \\
\hline S1 & 64 & 52.9 & 10 & 8.3 \\
\hline $\mathrm{S} 2$ & 22 & 18.2 & 2 & 1.7 \\
\hline S3 & 2 & 1.7 & 11 & 9.1 \\
\hline \multicolumn{5}{|l|}{ Pendidikan Terakhir } \\
\hline \multicolumn{5}{|l|}{ Ayah } \\
\hline SD & 2 & 1.7 & 18 & 14.9 \\
\hline SMP & 38 & 31.4 & 28 & 23.1 \\
\hline SMA & 55 & 45.5 & 63 & 52.1 \\
\hline S1 & 21 & 17.4 & 11 & 9.1 \\
\hline S2 & 5 & 4.1 & 1 & 0.8 \\
\hline S3 & 2 & 1.7 & 0 & 0 \\
\hline
\end{tabular}

Berdasarkan hasil penyajian data pada Tabel 1, didapatkan tingkat pendidikan terakhir ibu responden paling banyak di SMPN 1 yaitu S1 (52,9\%), diikuti dengan SMA/SLTA/SMK (25,6\%), S2 (18,2\%), SMP $(1,7 \%)$, dan S3 $(1,7 \%)$. Sedangkan, tingkat pendidikan terakhir ibu di SMPN 23 majoritas adalah SMA $(54,5 \%)$, kemudian SMP $(26,4 \%)$, SD $(9,1 \%)$, S3 $(9,1 \%), \mathrm{S} 1(8,3 \%)$, dan akhir sekali adalah S2 $(1,7 \%)$. 
Tabel 2. Distribusi karakteristik responden di SMPN 1 dan SMPN 23 Padang menurut penghasilan orang tua

\begin{tabular}{rcccc}
\hline \multirow{2}{*}{ Variabel } & \multicolumn{2}{c}{ SMPN 1 } & \multicolumn{2}{c}{ SMPN 23 } \\
\cline { 2 - 5 } & $\mathbf{f}$ & $\%$ & $\mathbf{f}$ & $\%$ \\
\hline Penghasilan & & & & \\
Orang Tua (Rp.) & & & & \\
$<1.500 .000$ & 3 & 2.5 & 36 & 29.8 \\
$1.500 .000-$ & 19 & 15.7 & 42 & 34.7 \\
2.500 .000 & & & & \\
$2.500 .000-$ & 23 & 19.0 & 30 & 24.8 \\
3.500 .000 & & 62.8 & 13 & 10.7 \\
$>3.500 .000$ & 76 & & & \\
\hline
\end{tabular}

Orang tua responden di SMPN 1 majoritas memiliki tingkat penghasilan tinggi (19\%), selebihnya adalah sangat tinggi $(17,4 \%)$, sedang $(15,7 \%)$, dan rendah $(2,5 \%)$. Sementara itu, orang tua responden di SMPN 23 kebanyakan memiliki tingkat penghasilan sedang $(34,7 \%)$, selebihnya rendah $(29,8 \%)$, tinggi $(24,8 \%)$ dan sangat tinggi $(10,7 \%)$.

Tabel 3. Gambaran tingkat pengetahuan pada siswi SMPN 1 dan SMPN 23 Padang tahun ajaran 2018/2019

\begin{tabular}{|c|c|c|c|}
\hline Variabel & $\begin{array}{c}\text { Rerata } \pm \\
\text { SD }\end{array}$ & $\begin{array}{l}\text { Minimal- } \\
\text { Maksimal }\end{array}$ & $95 \% \mathrm{Cl}$ \\
\hline \multicolumn{4}{|l|}{ Tingkat } \\
\hline \multicolumn{4}{|l|}{ Pengetahuan } \\
\hline SMPN 1 & $\begin{array}{l}6,14 \pm \\
0,879\end{array}$ & $4-10$ & $\begin{array}{l}5,98- \\
6,30\end{array}$ \\
\hline SMPN 23 & $\begin{array}{c}5,84 \pm \\
1,118\end{array}$ & $2-8$ & $\begin{array}{l}5,64- \\
6,04\end{array}$ \\
\hline \multicolumn{4}{|l|}{ Sikap Personal } \\
\hline \multicolumn{4}{|l|}{ Hygiene } \\
\hline SMPN 1 & $\begin{array}{c}24,73 \pm \\
3,050\end{array}$ & $7-28$ & $\begin{array}{l}24,18- \\
25,28\end{array}$ \\
\hline SMPN 23 & $\begin{array}{c}23,19 \pm \\
2,514\end{array}$ & $17-28$ & $\begin{array}{l}22,74- \\
23,64\end{array}$ \\
\hline $\begin{array}{l}\text { Perilaku } \\
\text { Personal } \\
\text { Hygiene }\end{array}$ & & & \\
\hline SMPN 1 & $\begin{array}{c}16,55 \pm \\
1,897\end{array}$ & $12-21$ & $\begin{array}{l}16,20- \\
16,89\end{array}$ \\
\hline SMPN 23 & $\begin{array}{c}16,27 \pm \\
1,713\end{array}$ & $11-20$ & $\begin{array}{l}15,96- \\
16,58\end{array}$ \\
\hline
\end{tabular}

Hasil analisis didapatkan rata-rata nilai tingkat pengetahuan di SMPN 1 adalah 6,14 (95\% Cl: 5,98$6,30)$ dengan standar deviasi 0,879 , dan nilai terendah
4 dan tertinggi 10 sedangkan di SMPN 23 adalah 5,84 (95\% Cl: 5,64-6,04), dengan standar deviasi 1,118 dan nilai terendah 2 dan tertinggi 8 .

Rerata sikap berdasarkan total nilai di SMPN 1 adalah 24,73 (95\% Cl: 24,18-25,28) dengan standar deviasi 3,05 , dan nilai terendah 7 dan tertinggi 28 sedangkan di SMPN 23 adalah 23,19 (95\% Cl: 22,7423,64), dengan standar deviasi 2,514 dan nilai terendah 17 dan tertinggi 28.

Nilai rerata perilaku berdasarkan total nilai di SMPN 1 adalah 16,55 (95\% Cl: 16,20-16,89) dengan standar deviasi 1,897, dan nilai terendah 12 dan tertinggi 21 sedangkan di SMPN 23 adalah 16,27 (95\% Cl: 15,96-16,58), dengan standar deviasi 1,713 dan nilai terendah 11 dan tertinggi 20 .

Tabel 4. Distribusi Responden menurut kejadian gejala vaginitis di SMPN 1 dan SMPN 23

\begin{tabular}{ccc}
\hline $\begin{array}{c}\text { Gejala vaginitis } \\
\text { berdasarkan Lokasi }\end{array}$ & Jumlah & Persentase \\
\hline SMPN 1 & 23 & 19 \\
Ada & 98 & 81 \\
Tidak ada & & \\
\hline SMPN 23 & 32 & 26.4 \\
Ada & 89 & 73.6 \\
\hline
\end{tabular}

Distribusi kejadian gejala vaginitis pada kedua sekolah didapatkan lebih banyak responden di SMPN 23 yang memiliki gejala vaginitis yaitu 32 orang $(26,4 \%)$ berbanding di SMPN 1 sebanyak 23 orang (19\%).

Tabel 5. Hubungan pengetahuan dengan gejala vaginitis pada siswi SMPN 1 dan SMPN 23 Padang tahun ajaran 2018/2019

\begin{tabular}{|c|c|c|c|c|c|c|}
\hline \multirow[t]{3}{*}{ Lokasi } & \multirow{3}{*}{$\begin{array}{c}\text { Tingkat } \\
\text { Pengeta } \\
\text { huan }\end{array}$} & \multicolumn{4}{|c|}{ Gejala Vaginitis } & \multirow{3}{*}{$\mathbf{p}$} \\
\hline & & \multicolumn{2}{|c|}{ Tidak ada } & \multicolumn{2}{|c|}{ Ada } & \\
\hline & & $f$ & $\%$ & $f$ & $\%$ & \\
\hline & Rendah & 0 & 0 & 0 & 0 & 0.558 \\
\hline \multirow[t]{2}{*}{ SMPN 1} & Sedang & 70 & 82.4 & 15 & 17.6 & \\
\hline & Tinggi & 28 & 77.8 & 8 & 22.2 & \\
\hline SMPN & Rendah & 3 & 100 & 0 & 0 & 0.011 \\
\hline \multirow[t]{2}{*}{23} & Sedang & 52 & 65 & 28 & 35 & \\
\hline & Tinggi & 34 & 83.5 & 4 & 10.5 & \\
\hline
\end{tabular}


Berdasarkan Tabel 5, tidak ada responden di SMPN 1 berada di tingkat pengetahuan rendah. Majoritas memiliki pengetahuan sedang yaitu sebanyak 85 responden dengan 17,6\% diantaranya memiliki gejala vaginitis. Sementara itu, majoritas responden di SMPN 23 memiliki tingkat pengetahuan mengenai personal hygiene yang sedang yaitu sebanyak 80 siswi dan 35\% diantaranya pernah mengalami gejala vaginitis.

Tidak terdapat hubungan yang signifikan antara pengetahuan dengan gejala vaginitis yang pernah dialami oleh responden di SMPN 1 dengan $p=0,558$ ( $p>0,05)$. Namun, terdapat hubungan yang signifikan antara pengetahuan dengan gejala vaginitis pada responden di SMPN 23 dengan $p=0,011(p<0,05)$.

Tabel 6. Hubungan sikap personal hygiene dengan gejala vaginitis pada siswi SMPN 1 dan SMPN 23 Padang tahun ajaran 2018/2019

\begin{tabular}{|c|c|c|c|c|c|c|}
\hline \multirow[t]{3}{*}{ Lokasi } & \multirow{3}{*}{$\begin{array}{c}\text { Sikap } \\
\text { Personal } \\
\text { Hygiene }\end{array}$} & \multicolumn{4}{|c|}{ Gejala Vaginitis } & \multirow{3}{*}{$p$} \\
\hline & & \multicolumn{2}{|c|}{$\begin{array}{c}\text { Tidak } \\
\text { ada }\end{array}$} & \multicolumn{2}{|c|}{ Ada } & \\
\hline & & $f$ & $\%$ & $f$ & $\%$ & \\
\hline SMPN & Negatif & 12 & 92.3 & 1 & 7.7 & 0.458 \\
\hline 1 & Positif & 86 & 79.6 & 22 & 20.4 & \\
\hline SMPN & Negatif & 20 & 57.1 & 15 & 42.9 & 0.013 \\
\hline 23 & Positif & 69 & 80.2 & 17 & 19.8 & \\
\hline
\end{tabular}

Responden di SMPN 1 paling banyak memiliki sikap yang positif mengenai personal hygiene namun $20,4 \%$ diantaranya masih memiliki gejala vaginitis. Sementara itu, responden di SMPN 23 juga lebih banyak menunjukkan sikap yang positif mengenai personal hygiene, dengan 19,8\% diantaranya masih memiliki gejala vaginitis.

Tidak terdapat hubungan yang signifikan antara sikap personal hygiene dengan gejala vaginitis oleh responden di SMPN 1 dengan $p=0,458 \quad(p>0,05)$. Namun, terdapat hubungan yang signifikan antara pengetahuan dengan gejala vaginitis pada responden di SMPN 23 dengan $p=0,013(p<0,05)$.
Tabel 7. Hubungan perilaku personal hygiene dengan gejala vaginitis pada siswi SMPN 1 dan SMPN 23 Padang tahun ajaran 2018/2019

\begin{tabular}{|c|c|c|c|c|c|c|}
\hline \multirow[t]{3}{*}{ Lokasi } & \multirow{3}{*}{$\begin{array}{l}\text { Perilaku } \\
\text { Personal } \\
\text { Hygiene }\end{array}$} & \multicolumn{4}{|c|}{ Gejala Vaginitis } & \multirow{3}{*}{$\mathbf{p}$} \\
\hline & & \multicolumn{2}{|c|}{ Tidak ada } & \multicolumn{2}{|c|}{ Ada } & \\
\hline & & $f$ & $\%$ & $f$ & $\%$ & \\
\hline SMPN & Buruk & 29 & 72.5 & 11 & 27.5 & 0.138 \\
\hline 1 & Baik & 69 & 85.2 & 12 & 14.8 & \\
\hline SMPN & Buruk & 28 & 77.8 & 8 & 22.2 & 0.615 \\
\hline 23 & Baik & 61 & 61 & 24 & 28.2 & \\
\hline
\end{tabular}

Pada responden di kedua sekolah majoritas memiliki perilaku personal hygiene yang baik. Namun begitu, masih ada diantaranya yang mengalami gejala vaginitis dengan persentase di SMPN 1 yaitu $14,8 \%$ dan di SMPN 23 yaitu 28,2\%.

Tidak terdapat hubungan yang signifikan antara perilaku personal hygiene dengan gejala vaginitis yang pernah dialami oleh responden di SMPN 1 dengan $p=0,138(p>0,05)$ dan di SMPN 23 dengan $p=0,615$ $(p>0,05)$.

\section{PEMBAHASAN}

\section{Karakteristik Responden}

Tingkatan pendidikan orang tua terutama ibu karena pengetahuan, sikap, dan perilaku dibentuk sejak usia dini dimulai dari keluarga. Dalam konteks pembentukan perilaku personal hygiene, ibu terutamanya memiliki peran yang penting dengan mengajarkan anak perempuannya mengenai kebersihan diri yang baik agar infeksi genitalia seperti vaginitis dapat dicegah. ${ }^{12}$

Tingkat keadaan ekonomi keluarga yang direpresentasikan melalui penghasilan orang tua juga berperan sebagai prasarana atau wahana anak perempuan dalam mendapatkan informasi tambahan mengenai personal hygiene dan memengaruhi dalam pemenuhan kebutuhan akses air, sabun, dan sanitary pad sehingga perilaku personal hygiene yang baik dapat terbentuk. ${ }^{13}$ 
Gambaran Tingkat Pengetahuan, Sikap, dan Perilaku Personal Hygiene pada Siswi SMPN 1 dan SMPN 23 Padang

Hasil analisis univariat mendapatkan bahwa tingkat pengetahuan responden di SMPN 1 lebih tinggi (rerata $=6,14$ ) berbanding responden di SMPN 23 (rerata $=5,84)$. Hal ini sejalan dengan penelitian Wan Muda et al yang dijalankan di Malaysia bahwa tingkat pengetahuan responden mengenai kebersihan diri di kota lebih tinggi berbanding yang tinggal di pinggir kota. Hal ini juga sejalan dengan penelitian oleh 36 bahwa penduduk di kota 1,8 kali lebih tinggi tingkat pengetahuan mengenai manajemen kebersihan menstruasi berbanding di pinggir kota. ${ }^{14}$

Faktor lokasi dapat memengaruhi tingkat pengetahuan seseorang terhadap manajemen kebersihan diri terutama saat menstruasi. Jika dilihat dari tabel karakteristik responden, terdapat perbedaan dari jumlah responden yang memiliki orang tua yang berpendidikan tinggi. Semakin tinggi tingkat pendidikan orang tua maka semakin luas ketersediaan sumber informasi mengenai manajemen menarche dan menstruasi yang diberikan kepada anak perempuannya. Pendidikan dari ibu memiliki pengaruh yang besar terhadap praktek personal hygiene dan masalah ginekologi pada remaja perempuan yang baru menarche. ${ }^{8}$ Hasil penelitian Verma et al di India mendapatkan bahwa sebanyak $87,3 \%$ perempuan menggunakan kain dan 10,6\% menggunakan sanitary pad. Sebanyak 33,6\% disebabkan oleh kurangnya pengetahuan mengenai manajemen menstruasi. ${ }^{9}$

Sikap responden terhadap personal hygiene adalah lebih baik di SMPN 1 (mean=24,73) berbanding di SMPN 23 (mean=23,19). Hal ini sejalan juga dengan penelitian yang dilakukan oleh Thakre et al, 2011 yang mendapatkan bahwa sikap personal hygiene penduduk kota lebih baik berbanding di pinggir kota. ${ }^{8}$

Berdasarkan tabel tersebut juga didapatkan bahwa perilaku personal hygiene responden lebih baik di SMPN 1 (mean=16,55) berbanding di SMPN 23 (mean=16,27).
Hubungan Pengetahuan Personal Hygiene dengan Pengalaman Gejala Vaginitis di SMPN 1 dan SMPN 23 Padang

Berdasarkan Tabel 5, dapat dilihat bahwa variabel tingkat pengetahuan dengan gejala vaginitis di SMPN 1 Padang menunjukan hubungan yang tidak signifikan $(p=0,558)$, artinya tingkat pengetahuan tidak berpengaruh terhadap ada atau tidaknya gejala vaginitis pada populasi tersebut. Namun begitu, hasil yang berbeda didapatkan terhadap responden di SMPN 23 Padang dimana hubungan pengetahuan dengan gejala vaginitis di SMPN 1 Padang menunjukan kekuatan hubungan yang signifikan $(p=0,011)$, artinya tingkat pengetahuan berpengaruh terhadap ada atau tidaknya gejala vaginitis pada populasi tersebut. Hasil yang didapatkan Olfa (2016) di SMPN 23 Padang sejalan dengan penelitian yang dilakukan di Bantul dimana peneliti tersebut mendapatkan adanya keterkaitan antara tingkat pengetahuan dengan keputihan patologis $(p=0,01)$ yang merupakan salah satu jenis dari vaginitis. ${ }^{15}$

Tingkat pendidikan merupakan salah satu faktor yang memengaruhi pengetahuan. Semakin tinggi tingkat pendidikan seseorang maka akan semakin mudah seseorang menerima dan menyampaikan informasi tersebut kepada orang lain. Hal ini juga akan meningkatkan inisiatif seseorang dalam mencari informasi tambahan mengenai suatu hal. Pengetahuan yang kurang mengenai menstruasi dan siklus menstruasi akan menyebabkan seseorang tidak siap ketika menarche sehingga MHM tidak terlaksana dengan benar. Orang tua, guru, dan teman merupakan sumber informasi yang paling banyak dan memiliki peran penting dalam kesediaan seseorang menghadapi menarche. ${ }^{3}$ Pada penelitian ini, perbedaan kemaknaan hubungan pengetahuan personal hygiene dengan gejala vaginitis pada kedua lokasi bisa disebabkan oleh adanya perbedaan aspek tingkat pengetahuan ibu dan ayah sebagai sumber informasi bagi anak perempuan, tingkat ekonomi, dan pengalaman manajemen kebersihan diri terutama saat menstruasi pada anak perempuan. Ketiga aspek ini 
ini dijelaskan pada penelitian yang dilakukan di Malaysia. yang mendapatkan bahwa tingkat ekonomi $(p=0,001)$, tingkat pendidikan $(p=0,001)$ dan pengalaman $(p=0,001)$ memiliki keterkaitan dengan tingkat pengetahuan personal hygiene sebagai bentuk pencegahan terjadinya vaginitis. ${ }^{14}$

\section{Hubungan Sikap Personal Hygiene dengan Pengalaman Gejala Vaginitis di SMPN 1 Padang dan SMPN 23 Padang}

Pada aspek sikap, peneliti mendapatkan hubungan yang signifikan antara sikap personal hygiene dengan gejala vaginitis yang pernah dialami oleh siswi di SMPN 23 Padang $(p=0,013)$. Hal ini sejalan dengan penelitian di Universitas Gadjah Mada bahwa terdapat hubungan antara sikap personal hygiene dengan gejala vaginitis $(p=0,046){ }^{15}$ Sementara itu, tidak ada hubungan yang signifikan antara sikap personal hygiene dengan gejala vaginitis yang pernah dialami oleh siswi di SMPN 1 Padang $(p=0,058)$. Hasil penelitian yang dilakukan di SMPN 1 Padang sejalan dengan penelitian Adawiyah (2015) yang dilakukan oleh di Tangerang Selatan yang menunjukkan penelitiannya mengenai sikap dengan keputihan patologis tidak memiliki hubungan yang signifikan $(p=0,173){ }^{16}$

Dalam konteks penelitian ini, hasil yang berbeda di kedua sekolah bisa disebabkan oleh faktor pengalaman pribadi, orang lain, kebudayaan, media massa, lembaga pendidikan dan faktor emosional diatas memiliki distribusi yang berbeda.

\section{Hubungan Perilaku Personal Hygiene dengan Pengalaman Gejala Vaginitis di SMPN 1 Padang dan SMPN 23 Padang}

Berdasarkan Tabel 7, tidak terdapat hubungan perilaku personal hygiene dengan gejala vaginitis yang pernah dialami oleh siswi SMPN $1(p=0,138)$ dan SMPN 23 Padang $(p=0,615)$. Hasil penelitian ini sejalan dengan penelitian yang dilakukan oleh Annisa Nurhayati, 2013 yang mendapatkan bahwa tidak terdapat hubungan antara perilaku personal hygiene dengan gejala vaginitis $(p=0,380) .{ }^{11}$

Gejala vaginitis dipengaruhi oleh berbagai faktor salah satunya adalah perilaku kebersihan diri yang diukur dari frekuensi penggunaan produk kebersihan vagina, pemakaian sanitary pad, bahan celana dalam dan sebagainya. Perilaku seseorang dipengaruhi oleh tiga faktor utama, yaitu faktor predisposing, enabling, dan reinforcing. Faktor predisposing yaitu pengetahuan, sikap, dan sosioekonomi dapat mengembangkan perilaku seseorang menjadi baik atau buruk. Hal ini bergantung pada media atau sumber informasi seseorang seperti orang tua, media massa, guru, kounselor, tenaga kesehatan dan lain-lain. Faktor enabling yaitu ketersediaan sarana dan prasarana di tempat kerja, sekolah, atau pelayanan kesehatan menyebabkan seseorang beradaptasi dan berkembang secara biologis sehingga berpengaruh terhadap perubahan perilaku dan kualitas kesehatan seseorang. Fasilitas air, sanitasi, dan kebersihan di sekolah yang kurang juga merupakan fenomena yang tidak jarang ditemukan di beberapa negara berkembang, termasuk Indonesia. Sebagian besar siswi mengaku bahwa kurangnya fasilitas ini menimbulkan rasa tidak nyaman karena tidak mendapatkan privasi yang cukup. Hal ini menyebabkan siswi lebih memilih tidak mengganti sanitary pad dan celana dalam selama lebih 8 jam, sehingga menyebabkan iritasi, gatal, dan perih pada genitalia.

Pada penelitian ini, walaupun seseorang berperilaku baik tetapi masih terjadi gejala vaginitis itu bisa disebabkan oleh berbagai faktor yang memengaruhi perilaku khususnya faktor enabling dan faktor reinforcing. Selain itu, peneliti juga berpendapat bahwa gejala vaginitis yang dialami bisa disebabkan oleh stres. Pada vaginitis, jumlah lactobacilli di vagina menurun dan menyebabkan kadar hidrogen peroksida berkurang sehingga mendorong pertumbuhan organisme patogen dan bakteri anaerob lainnya secara berlebihan. Bakteri anaerob akan memproduksi asam suksinat yang dapat menyebakan fungsi sel darah putih menurun. ${ }^{17}$ Seseorang akan semakin rentan terkena infeksi ketika dipaparkan dengan stres. Hal ini berhubungan dengan produksi hormon glukokortikoid dan katekolamin berlebihan yang dipengaruhi aksis hipotalamus-pituiter-adrenal dan aksis simpatis-adrenal-meduler. Beberapa penelitian mendapatkan stres sebagai salah satu faktor pemicu 
penurunan imunitas tubuh, seperti pada penurunan respons vaksinasi. ${ }^{5}$ Penelitian Nansel et al bahwa wanita yang mengalami stress memiliki risiko terkena vaginosis bakterialis $1,07-1,24$ kali lebih tinggi berbanding wanita yang tidak mengalami stress. $(p=0,0003) .^{18}$

\section{SIMPULAN}

Terdapat hubungan pengetahuan personal hygiene dengan gejala vaginitis pada siswi SMPN 23 Padang namun tidak terdapat hubungan pada siswi SMPN 1 Padang.

Terdapat hubungan sikap personal hygiene dengan gejala vaginitis pada siswi SMPN 23 Padang namun tidak terdapat hubungan pada siswi SMPN 1 Padang.

Tidak terdapat hubungan perilaku personal hygiene dengan gejala vaginitis baik pada siswi SMPN 1 Padang maupun SMPN 23 Padang

\section{DAFTAR PUSTAKA}

1. Haver J, Long JL, Lee S. Menstrual hygiene management operational guidelines. United States of America: Save The Children International. 2014;1 (246):8-25

2. Hainer BL, Gibson MV. Vaginitis: Diagnosis and treatment. Am Fam Physician. 2011;83(7):807-15.

3. World Health Organization (WHO). A multi-country study on gender, sexuality and vaginal practices: implications for sexual health. WHO. 2012;1(3610):1-4.

4. Sommer M, Sahin M. Advancing the global agenda for menstrual hygiene management for schoolgirls. Am J Public Health. 2013;103(9):1556-9.

5. Lufiati DE. Faktor-faktor yang berhubungan dengan perilaku personal hygiene organ genitalia pada pelajar putri di SMK N 7 Surakarta (skripsi). Surakarta. Universitas Muhammadiyah Surakarta; 2015.

6. Das P, Baker KK, Dutta A, Swain T, Sahoo S, Das $\mathrm{BS}$, et al. Menstrual hygiene practices, WASH access and the risk of urogenital infection in women from Odisha, India. PLoS One. 2015;10(6):1-17.
7. Tegegne T, Sisay M, Keerti J, Pravin Y, Adhikari P, Kadel B, et al. Menstrual hygiene management and school absenteeism among female adolescent students in Northeast Ethiopia. BMC Public Health [Internet]. 2014;14(1):1118.

8. Thakre SB, Thakre SS, Reddy M, Rathi N, Pathak K, Ughade S. Menstrual hygiene: Knowledge and practice among adolescent school girls of Saoner, Nagpur District. J Clin Diagnostic Res. 2011;5(5):1027-33.

9. Verma $P$, Pandya $C$, Ramanuj V, Singh $M$. Menstrual pattern of adolescent school girls of Bhavnagar (Gujarat). Natl J Integr Res Med. $2011 ; 2(1): 38-40$.

10. Hamed AG. The Impact of genital hygiene practices on the occurrence of vaginal infection and the development of a nursing fact sheet as prevention massage for vulnrable women. IOSR $\mathrm{J}$ Nurs Heal Sci. 2015;4(6).

11. Nurhayati A. Hubungan pengetahuan, sikap, dan perilaku vaginal hygiene terhadap kejadian keputihan patologis pada remaja putri usia 13-17 tahun di daerah Pondok Cabe llir (skripsi). Universitas Islam Negeri Syarif Hidayatullah; 2013.

12. Dhara P, Janmesh S, Geeta K. Menstrual hygiene: knowledge and practice among adolescent girls of rural Kheda district. Natl J Community Med. 2015;6(3):349-53.

13. Nagar S, Aimol KR. Knowledge of adolescent girls regarding menstruation in tribal areas of Meghalaya. Stud Tribes Tribals. 2010;8(1):27-30.

14. Wan Muda WM, Wong LP, Tay ST. Prevention practices of vaginitis among Malaysian women and its associated factors. J Obstet Gynaecol (Lahore). 2018;38(5):708-15.

15. Olfa PA. Hubungan pengetahuan, sikap, dan perilaku personal hygiene dengan kejadian keputihan patologis pada remaja putri kelas IX di MTSN Wonokromo Bantul (skripsi). Yogyakarta. Universitas Gadjah Mada; 2016.

16. Adawiyah KD. Hubungan pengetahuan, sikap dan perilaku kesehatan reproduksi dengan kejadian keputihan (fluor albus) pada siswi SMA se-derajat di wilayah Tangerang Selatn (skripsi). Universitas Islam Negeri Syarif Hidayatullah; 2015. 
17. Jones AW, Hylén $L$, Svensson $E$, Helander A. Storage of specimens at 4 degrees $C$ or addition of sodium fluoride $(1 \%)$ prevents formation of ethanol in urine inoculated with Candida albicans. J Anal Toxicol. 1999 Sep;23(5):333-6.
18. Nansel TR, Riggs MA, Yu KF, Andrews WW, Schwebke JR, et al. The association of psychosocial stress and bacterial vaginosis in a longitudinal cohort. Am J Obstet Gynecol. 2006; 194(2): 381-6. 